\title{
Emisi Karbon dan Produk Domestik Bruto: Investigasi Hipotesis Environmental Kuznets Curve (EKC) pada Negara Berpendapatan Menengah di Kawasan ASEAN
}

\author{
Carbon Emission and Gross Domestic Product: A Hypothetical Investigation \\ on Environmental Kuznets Curve (EKC) in ASEAN Middle-Income Countries
}

\section{Muhamad Ameer Noor ${ }^{1}$}

Jurusan IImu Ekonomi, Fakultas Ekonomi dan Bisnis, Universitas Brawijaya, Malang, Indonesia

\author{
Putu Mahardika Adi Saputra² \\ Jurusan IImu Ekonomi, Fakultas Ekonomi dan Bisnis, Universitas Brawijaya, Malang, Indonesia
}

Artikel Masuk : 12 Agustus 2020

Artikel Diterima : 18 November 2020

Tersedia Online : 31 Desember 2020

\begin{abstract}
Abstrak: Para pengambil kebijakan di dunia telah lama memerhatikan emisi karbon karena risiko pemanasan global. Sejalan dengan itu, banyak studi tentang Kurva Lingkungan Kuznets (Environmental Kuznets Curve/EKC) menggunakan emisi karbon sebagai indikator degradasi lingkungan. Penelitian ini bertujuan untuk menginvestigasi eksistensi EKC dan melihat ragam hubungan antara emisi karbon dan Produk Domestik Bruto (PDB) per kapita di empat negara berpendapatan menengah (middle-income) di kawasan ASEAN. Penelitian dilakukan terhadap data tahunan 1971-2014 di Indonesia, Thailand, Filipina, dan Malaysia dengan menggunakan model simultan two-stage least square (2SLS) untuk setiap negara. Variabel-variabel utama yang diteliti adalah PDB per kapita, kuadrat dari PDB per kapita, dan emisi karbon dengan didukung variabel-variabel lain yang berperan sebagai variabel kontrol. Validasi eksistensi EKC dilakukan dengan melihat pengaruh PDB dan PDB kuadrat terhadap emisi karbon, sedangkan ragam hubungan PDB dengan emisi karbon dilihat dari hasil pengaruh simultan antarkeduanya. Hasil analisis menemukan bahwa pertama, eksistensi EKC tidak dapat divalidasi pada keempat negara karena kebijakan energi dan transportasi di tiap-tiap negara belum mampu menekan degradasi lingkungan dan kedua, pengaruh positif berjalan satu arah dari emisi karbon ke PDB di keempat negara. Nilai koefisien pengaruh emisi karbon terhadap PDB menunjukkan bahwa negara dengan tingkat efisiensi polusi emisi karbon tertinggi adalah Thailand dan selanjutnya disusul oleh Indonesia, Filipina, dan Malaysia. Berdasarkan hasil penelitian, kebijakan reduksi emisi karbon pada keempat negara tersebut direkomendasikan harus dapat lebih berfokus pada mempermudah masuknya teknologi ramah lingkungan dari negara maju untuk trade-off antara ekonomi dan lingkungan.
\end{abstract}

\footnotetext{
${ }^{1}$ Korespondensi Penulis: Jurusan Ilmu Ekonomi, Fakultas Ekonomi dan Bisnis, Universitas Brawijaya, Malang, Indonesia Email: ameer.noor@student.ub.ac.id

${ }^{2}$ Korespondensi Penulis: Jurusan Ilmu Ekonomi, Fakultas Ekonomi dan Bisnis, Universitas Brawijaya, Malang, Indonesia Email: putu@ub.ac.id
} 
Kata Kunci: ASEAN; emisi karbon; kurva lingkungan Kuznets; negara berpendapatan menengah

\begin{abstract}
Policymakers in the world are concerned with carbon emission due to the risk of global warming. Many studies on Environmental Kuznets Curve (EKC) consider carbon emission as a proxy of environmental degradation. This study aimed to investigate the existence of EKC and identify variations of relationships between carbon emissions and GDP per capita in ASEAN middle-income countries. The study was conducted on Indonesia, Thailand, Philippines, and Malaysia based on 1971-2014 time series data using a simultaneous model (2SLS) for each country. The main variables studied were GDP per capita, square of GDP per capita, and carbon emission supported by other variables as the controlling variables. Validation on EKC existence was determined by GDP and GDP squared influence on carbon emission, while variations of relationship between GDP and carbon emission were based on the result of simultaneous regressions. The results showed that the existence of the EKC could not be validated in all countries because energy and transportation policies in each country failed to reduce the emission. On the other hand, carbon emission had a positive unidirectional influence on GDP in all countries. The effect of carbon emission coefficient to GDP showed that Thailand ranked the highest in $\mathrm{CO}_{2}$ efficiency, followed by Indonesia, Philippines, and Malaysia. This study recommended that carbon emission reduction policies in the four countries should focus more to easier access to environmentally friendly technology from developed countries for ensuring trade-offs between the economy and environment.
\end{abstract}

Keywords: ASEAN; carbon emission; environmental kuznets curve; middle-income countries

\title{
Pendahuluan
}

Pertumbuhan ekonomi yang mampu meningkatkan kesejahteraan masyarakat secara umum merupakan target pembangunan yang dikejar oleh hampir seluruh negara di dunia. Namun demikian, pertumbuhan ekonomi itu sendiri terkadang dapat menciptakan trade-off berupa eksternalitas negatif yang dapat menurunkan kesejahteraan masyarakat. Dalam kasus eksternalitas negatif yang masif seperti perubahan iklim (climate change) akibat emisi karbon, Tol (2012) memproyeksikan penurunan kesejahteraan total (total welfare loss) apabila kenaikan suhu mencapai titik tertentu. Serupa dengan temuan tersebut, studi Hitz \& Smith (2004) mengindikasikan dampak negatif eksponensial pada beberapa sektor apabila kenaikan suhu mencapai tingkat tertentu. Kedua studi juga menekankan adanya potensi dampak negatif yang lebih besar dari proyeksi yang ada karena kompleksitas dampak perubahan iklim terhadap berbagai aspek dalam ekosistem yang sulit diukur. Di samping itu, emisi karbon juga dapat berdampak negatif terhadap kesehatan manusia sebagaimana disinggung dalam studi Gunawan \& Budi (2017).

Hipotesis Kurva Lingkungan Kuznets atau Environmental Kuznets Curve (EKC) berusaha menjelaskan keterkaitan antara pertumbuhan ekonomi dan kerusakan lingkungan (Stern, 2014). Menurut hipotesis EKC sebagaimana ditunjukkan pada Gambar 1, pembangunan ekonomi yang direpresentasikan dengan Produk Domestik Bruto (PDB) per kapita, pada tahap awal industrialisasi akan diiringi dengan peningkatan kerusakan lingkungan (Panayotou, 1993). Hal ini berkaitan dengan perilaku dan kebutuhan masyarakat untuk meningkatkan taraf ekonomi tanpa memedulikan dampaknya terhadap keberlanjutan jangka panjang. Setelah mencapai titik PDB per kapita tertentu, perekonomian akan bertransisi ke sektor jasa yang membutuhkan eksploitasi sumber daya lebih sedikit disertai peningkatan kesadaran lingkungan masyarakat, sehingga kerusakan lingkungan akan menurun. 
Organisasi untuk kerjasama ekonomi dan pembangunan atau Organisation for Economic Cooperation and Development (OECD) membuat 10 indikator utama lingkungan (Organisation for Economic Cooperation and Development, 2008). Salah satu indikator kerusakan lingkungan yang menjadi perhatian global saat ini adalah emisi Gas Rumah Kaca (GRK). Emisi GRK mendorong terjadinya pemanasan global dan perubahan iklim yang memiliki banyak dampak negatif terhadap kondisi sosial dan ekonomi manusia. Di antara dampak-dampak negatif tersebut adalah kenaikan air laut, penurunan ketersediaan air bersih, dan cuaca ekstrem. Berdasarkan data World Bank (2020), emisi GRK telah meningkat pesat $(93,51 \%)$ dari tahun 1970-2012, didorong oleh kebutuhan energi dunia yang meningkat seiring peningkatan aktivitas perekonomian. Emisi $\mathrm{CO}_{2}$ merupakan komponen emisi GRK yang paling diperhatikan karena menyumbang lebih dari dua per tiga emisi GRK per tahun 2012.

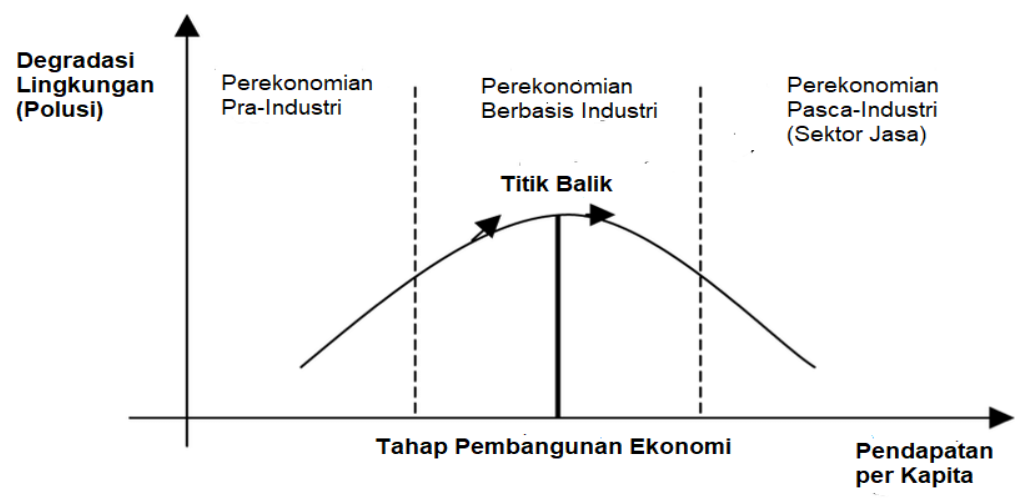

Sumber: Panayotou, 1993 (diolah)

Gambar 1. Kurva Lingkungan Kuznets (EKC)

Menurut Intergovernmental Panel on Climate Change (2018), kenaikan suhu dunia rata-rata telah mencapai $1{ }^{\circ} \mathrm{C}$. Dengan tren kenaikan emisi saat ini, kenaikan suhu diperkirakan akan mencapai tingkat irreversible losses $2^{\circ} \mathrm{C}$. Tingkat irreversible losses dimaksud adalah batas kenaikan suhu yang apabila terlewati, kerusakan alam menjadi sangat signifikan dan suhu akan cenderung terus meningkat. Berkaitan dengan isu tersebut, berbagai negara di dunia telah berkomitmen untuk mereduksi emisi karbon melalui perjanjian-perjanjian internasional seperti Protokol Kyoto tahun 1997 dan Perjanjian Paris tahun 2016. Dalam Perjanjian Paris, 185 dari 197 negara-negara yang ada di dunia berkomitmen untuk mereduksi emisi GRK dengan target yang beragam.

Berdasarkan dokumen United Nations Framework Convention on Climate Change (2016), Indonesia memiliki komitmen target reduksi emisi untuk tahun 2020 dan kembali diperbarui untuk tahun 2030. Dengan mempergunakan data historis kenaikan emisi periode tahun 2000-2010, target reduksi per tahun 2020 adalah sebesar 26\% (tanpa bantuan luar negeri) hingga 39\% (dengan bantuan luar negeri). Selanjutnya, target reduksi tahun 2030 diperbaharui menjadi sekitar 29\% (tanpa bantuan luar negeri) hingga 41\% (dengan bantuan luar negeri). Menurut uraian Partnership for Market Readiness (2018), Indonesia telah melaksanakan skema-skema seperti Clean Development Mechanism (CDM), Verified Carbon Standard (VCS), Joint Crediting Mechanism (JCM), Gold Standard, dan Plan Vivo untuk memenuhi target tersebut. Namun demikian, World Resources Institute (2017) mencatatkan per tahun 2017 reduksi emisi karbon Indonesia baru mencapai 19\%, masih jauh dari target komitmennya. Di samping itu, Indonesia juga tercatat sebagai penghasil 


\section{Emisi Karbon dan Produk Domestik Bruto: Investigasi Hipotesis Environmental Kuznets Curve .. .}

emisi terbesar ke-5 dunia, dan penghasil emisi berbasis hutan (forest-based emission) terbesar dunia saat terjadi kebakaran hutan besar (World Resources Institute, 2017).

Mayoritas negara ASEAN (termasuk Indonesia, Malaysia, Filipina dan Thailand) kerap diidentifikasikan sebagai negara berkembang yang berada dalam tahap awal pembangunan menurut hipotesis EKC. Oleh sebab itu, pengurangan kerusakan lingkungan sulit dilaksanakan karena adanya kebutuhan pembangunan ekonomi dan lemahnya kesadaran lingkungan masyarakat. Namun demikian, terdapat paradoks ketika dampak dari perubahan iklim sebenarnya akan lebih parah ditanggung oleh negara berkembang. Dalam konteks emisi $\mathrm{CO}_{2}$, alasan berpolusi demi untuk memenuhi kebutuhan ekonomi hampir sepenuhnya tidak dapat dibenarkan. Secara umum, seperti terlihat dalam Gambar 2, ekonomi dan emisi karbondioksida di Indonesia, Malaysia, Filipina dan Thailand cenderung menunjukkan tahap awal hipotesis EKC, yaitu sama-sama meningkat. Studi oleh Caraka et al. (2018) juga menunjukkan bahwa data emisi karbon dan produk domestik bruto di lingkup ASEAN terbukti memiliki korelasi.

Literatur-literatur terdahulu yang menginvestigasi eksistensi EKC dengan emisi $\mathrm{CO}_{2}$ sebagai indikator lingkungan menunjukkan hasil yang beragam. Studi data panel banyak negara oleh Grossman \& Krueger (1995) dan Uchiyama (2016) mampu memvalidasi eksistensi EKC. Studi negara secara individu pada negara maju seperti Ang (2007) dan Uchiyama (2016) juga dapat memvalidasi eksistensi EKC. Namun demikian, studi negara secara individu pada negara berkembang oleh Saboori et al. (2012), Azlina et al. (2014), dan Iskandar (2019) tidak dapat memvalidasi EKC. Selanjutnya, studi-studi yang meneliti hubungan antara emisi $\mathrm{CO}_{2}$ dan PDB per kapita juga menunjukkan hasil yang beragam. Hubungan beragam sebagaimana dimaksud, yaitu emisi $\mathrm{CO}_{2}$ dan $\mathrm{PDB}$ saling memengaruhi (Ghosh, 2010; Halicioglu, 2009; Shahbaz et al., 2013), hubungan satu arah ketika emisi $\mathrm{CO}_{2}$ memengaruhi PDB (Azlina et al., 2014; Lim et al., 2014), dan hubungan satu arah dengan PDB memengaruhi emisi $\mathrm{CO}_{2}$ (Anatasia, 2015; Ang, 2007; Hwang \& Yoo, 2014), dan tidak ada hubungan langsung di antara keduanya (Anatasia, 2015; Zhang \& Cheng, 2009).

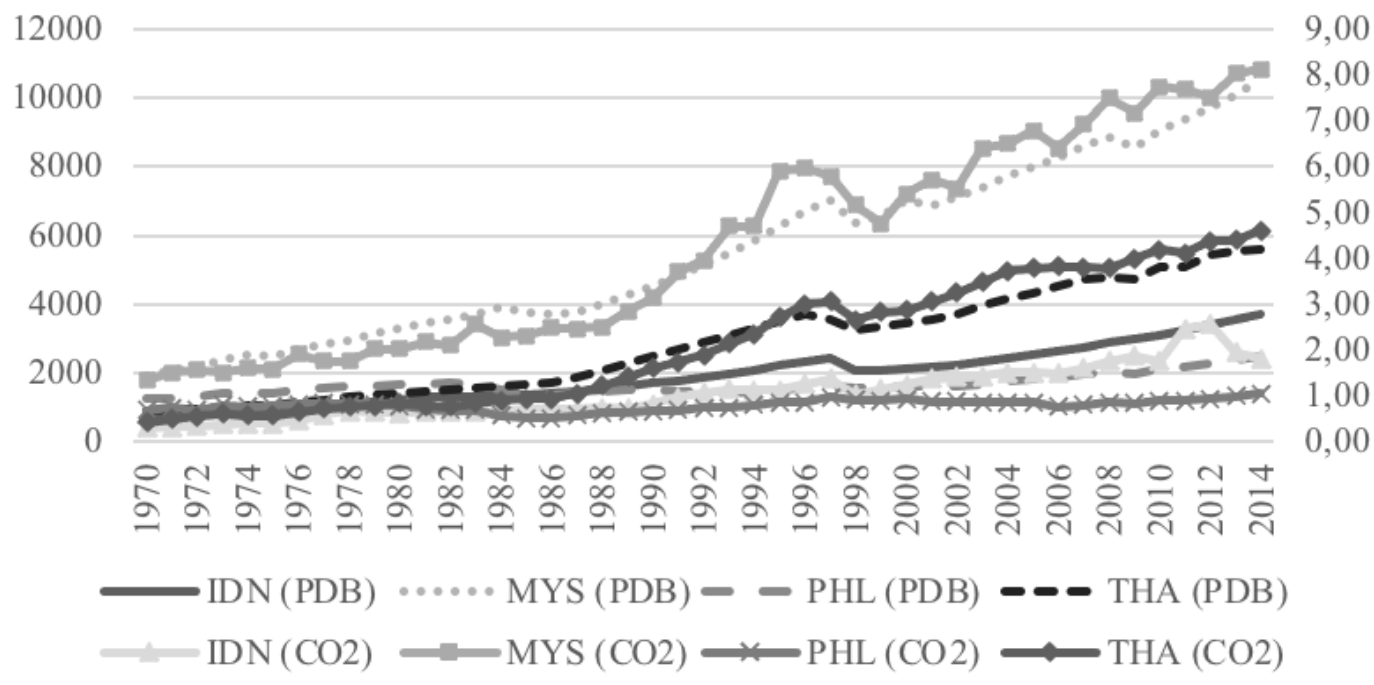

Keterangan: Sumbu vertikal kiri $=$ PDB dalam \$ Konstan 2010;

Sumbu vertikal kanan $=$ Emisi $\mathrm{CO}_{2}$ dalam metrik ton

Sumber: World Bank, 2020 (diolah)

Gambar 2. PDB dan Emisi $\mathrm{CO}_{2}$ per Kapita Indonesia, Malaysia, Filipina, dan Thailand 1970-2014 
Berkaitan dengan kompleksitas kondisi negara berkembang dalam konteks reduksi emisi karbon, penilaian perkembangan ekonomi dan emisi $\mathrm{CO}_{2}$ di Indonesia memerlukan beberapa perbandingan, terutama perbandingan yang berasal dari negara-negara yang memiliki karakteristik ekonomi dan region yang sama. Oleh karena itu, dalam penelitian ini, empat negara berpendapatan menengah (middle-income countries) lingkup ASEAN (Indonesia, Malaysia, Filipina, dan Thailand) dipilih menjadi objek penelitian. Pembatasan pada empat tersebut dikarenakan adanya keterbatasan rentang waktu data yang tersedia untuk negara-negara berpendapatan menengah ASEAN lainnya.

Penelitian ini bertujuan untuk menginvestigasi eksistensi EKC serta membandingkan hubungan antara $\mathrm{CO}_{2}$ dan PDB di Indonesia, Thailand, Filipina, dan Malaysia. Validasi eksistensi EKC di tiap-tiap negara diperlukan untuk melihat apakah negara tersebut perlu mewaspadai peningkatan taraf ekonomi yang tidak disertai peningkatan kesadaran lingkungan masyarakatnya. Perbandingan hubungan antara $\mathrm{CO}_{2}$ dan $\mathrm{PDB}$, beserta koefisien pengaruhnya dimaksudkan untuk melihat dampak lingkungan dari kebijakankebijakan ekonomi yang telah ditempuh, serta mencari rekomendasi kebijakan yang lebih baik untuk diterapkan ke depannya. Kemiripan dari empat negara tersebut diharapkan dapat menghasilkan rekomendasi yang dapat diterapkan antarnegara dalam konteks kebijakan pembangunan ekonomi ramah lingkungan.

\section{Metode Penelitian}

Model regresi yang dimanfaatkan untuk memvalidasi EKC dalam studi ini mengacu pada model standar yang dijabarkan oleh Uchiyama (2016), dengan variabel emisi $\mathrm{CO}_{2}$ dipengaruhi oleh PDB per kapita dan PDB per kapita kuadrat untuk membentuk hubungan kuadratik. Apabila PDB per kapita berpengaruh positif signifikan dan PDB per kapita kuadrat berpengaruh negatif signifikan, maka hipotesis EKC dapat divalidasi. Terdapat beberapa literatur dan studi terdahulu yang tercatat menggunakan konstruksi variabel yang sama untuk menginvestigasi hubungan antara PDB dan $\mathrm{CO}_{2}$ (Anatasia, 2015; Ang, 2007; Azlina et al., 2014; Ghosh, 2010; Halicioglu, 2009; Hwang \& Yoo, 2014; Lim et al., 2014; Shahbaz et al., 2013; Zhang \& Cheng, 2009).

Perbandingan hasil regresi antarnegara dilakukan dengan melihat arah hubungan pada tiap-tiap negara dan besaran koefisien pengaruh dari variabel-variabel utama yang dihasilkan oleh model regresi simultan Two-Stage Least Squares (2SLS). Data yang digunakan dalam penelitian ini merupakan data time-series tahunan dengan periode waktu tahun 1971-2014. Seluruh data, kecuali data variabel dummy, merupakan data sekunder yang bersumber dari World Bank (2020). Sebelum dilakukan analisis regresi, data yang akan digunakan ini terlebih dahulu melalui uji stasioneritas dengan metode Augmented Dickey-Fuller (ADF). Bentuk persamaan simultan untuk setiap negara ditampilkan pada persamaan (1) dan persamaan (2) untuk Negara Indonesia, persamaan (3) dan persamaan (4) untuk Negara Thailand, persamaan (5) dan persamaan (6) untuk Negara Filipina, dan persamaan (7) dan persamaan (8) untuk negara Malaysia.

1. Indonesia

$$
\begin{gathered}
\Delta\left(\mathrm{CO}_{2}\right)=\mathrm{C}_{\mathbf{1}}+\boldsymbol{\beta}_{1} \Delta(\mathrm{PDB})+\boldsymbol{\beta}_{2} \Delta(\text { PDB2 })+\boldsymbol{\beta}_{3} \Delta(\text { EN })+\boldsymbol{\beta}_{\mathbf{4}} \text { DIDN11 }+\boldsymbol{\beta}_{5} \text { DIDN13 }+\boldsymbol{\epsilon}_{1} \\
\Delta(\mathrm{PDB})=\mathrm{C}_{2}+\boldsymbol{\beta}_{6} \Delta\left(\mathrm{CO}_{2}\right)+\boldsymbol{\beta}_{\mathbf{7}} \text { TR }+\boldsymbol{\beta}_{\mathbf{8}} \text { TCS }+\boldsymbol{\beta}_{\mathbf{9}} \text { DIDN11 }+\boldsymbol{\beta}_{10} \text { DIDN13 }+\boldsymbol{\epsilon}_{2}
\end{gathered}
$$

2. Thailand

$$
\begin{gathered}
\Delta\left(\mathrm{CO}_{2}\right)=\mathrm{C}_{1 \mathrm{a}}+\beta_{1 \mathrm{a}} \Delta(\mathrm{PDB})+\beta_{2 \mathrm{a}} \Delta(\mathrm{PDB} 2)+\beta_{3 \mathrm{a}} \Delta(\mathrm{EN})+\beta_{4 \mathrm{a}} \mathrm{DTHA}+\epsilon_{1 \mathrm{a}} \\
\Delta(\mathrm{PDB})=\mathrm{C}_{2 \mathrm{a}}+\beta_{5 \mathrm{a}} \Delta\left(\mathrm{CO}_{2}\right)+\beta_{6 a} \Delta(\mathrm{TR})+\beta_{7 \mathrm{a}} \Delta(\mathrm{TCS})+\epsilon_{2 \mathrm{a}}
\end{gathered}
$$


3. Filipina

$$
\begin{gathered}
\Delta\left(\mathrm{CO}_{2}\right)=\mathrm{C}_{1 \mathrm{~b}}+\beta_{1 \mathrm{~b}} \Delta(\mathrm{PDB})+\beta_{2 \mathrm{~b}} \Delta(\mathrm{PDB} 2)+\beta_{3 \mathrm{~b}} \Delta(\mathrm{EN})+\epsilon_{1 \mathrm{~b}} \\
\Delta(\mathrm{PDB})=\mathrm{C}_{2 \mathrm{~b}}+\beta_{4 \mathrm{~b}} \Delta\left(\mathrm{CO}_{2}\right)+\beta_{5 b} \Delta(\mathrm{TR})+\beta_{6 \mathrm{~b}} \Delta(\mathrm{TCS})+\beta_{7 b} \mathrm{DPHL}+\epsilon_{2 \mathrm{~b}}
\end{gathered}
$$

4. Malaysia

$$
\begin{array}{|c|}
\Delta\left(\mathrm{CO}_{2}\right)=\mathrm{C}_{1 \mathrm{c}}+\beta_{1 \mathrm{c}} \Delta(\mathrm{PDB})+\beta_{2 \mathrm{c}} \Delta(\mathrm{PDB} 2)+\beta_{3 \mathrm{c}} \Delta(\mathrm{EN})+\beta_{4 \mathrm{c}} \text { DMYSEN }+\epsilon_{1 \mathrm{c}} \\
\Delta(\mathrm{PDB})=\mathrm{C}_{2 \mathrm{c}}+\beta_{5 \mathrm{c}} \Delta\left(\mathrm{CO}_{2}\right)+\beta_{6 c} \Delta(\mathrm{TR})+\beta_{7 \mathrm{c}} \Delta(\mathrm{TCS})+\beta_{8 c} \text { DMYS98 }+\epsilon_{2 \mathrm{c}}
\end{array}
$$

Pada delapan persamaan tersebut, variabel $\mathrm{CO}_{2}$ didefinisikan sebagai emisi $\mathrm{CO}_{2}$ per kapita dengan satuan kilogram, sedangkan variabel $\mathrm{PDB}$ dan $\mathrm{PDB}^{2}$ secara berturut-turut adalah PDB per kapita dan kuadrat dari PDB per kapita dalam satuan US\$ dengan tahun dasar 2010. Variabel $E N$ dimaknai sebagai konsumsi energi dalam satuan setara kilogram minyak per kapita, kemudian $T R$ adalah rasio perdagangan terhadap PDB dan TCS adalah kontribusi total konsumsi terhadap PDB. Kedua variabel yang disebutkan terakhir diukur dalam satuan persentase. Notasi $\Delta$ mengartikan bentuk first difference.

Selanjutnya, untuk tiap-tiap negara terdapat tambahan beberapa variabel dummy yang berfungsi sebagai variabel kontrol. Variabel-variabel dummy tersebut menggambarkan fenomena yang memiliki pengaruh signifikan pada periode tertentu dalam tiap-tiap model regresi (keterangan: $1=$ periode tahun terjadinya fenomena, dan $0=$ periode tahun normal ketika tidak ada fenomena). Pada persamaan (1) dan (2) yang menggambarkan hubungan antara variabel $\mathrm{CO}_{2}$ dan PDB di Indonesia, terdapat dua variabel dummy, yaitu DIDN11 dan DIDN13. Variabel DIDN11 merepresentasikan fenomena terjadinya dampak sampingan moratorium lahan Indonesia. Tahun 2011 terjadi lonjakan emisi yang diduga akibat sementara dari moratorium pembukaan lahan 2011. Fenomena tersebut didukung dugaan dari Bachelard (2014) data deforestasi dari Tsujino et al. (2016), dan periode recovery harga sawit pasca krisis 2008 berdasarkan data Index Mundi (Index Mundi, 2020). Variabel DIDN13 merepresentasikan berakhirnya dampak sampingan moratorium lahan Indonesia tersebut di tahun 2013.

Pada persamaan (3) untuk negara Thailand dan persamaan (8) untuk negara Malaysia, terdapat variabel dummyyang merepresentasikan fenomena krisis 1998 di kedua negara. Variabel tersebut dinotasikan sebagai DTHA untuk persamaan Thailand dan DMYS98 untuk persamaan Malaysia. Penggunaan variabel dummy untuk menjelaskan dampak krisis 1998 di negara ASEAN juga digunakan dalam beberapa penelitian (Detragiache \& Gupta, 2006; Ghosh \& Rajan, 2009; Holden et al., 2005; Supriadi \& Ismail, 2012).

Sementara itu, pada persamaan (6) yang menggambarkan model regresi PDB untuk Filipina, penambahan variabel dummy DPHL merepresentasikan krisis ekonomi Filipina pada dua periode, tahun 1984-1985. Penggunaan variabel dummy untuk dampak krisis 1984-1985 di Filipina juga digunakan dalam penelitian Subramaniam \& Baharumshah (2011). Pada persamaan (7), model regresi $\mathrm{CO}_{2}$ di Malaysia, terdapat penambahan variabel dummy DMYSEN merepresentasikan perubahan kebijakan energi pada tahun 1995, yang diduga berdampak pada lonjakan emisi. Menurut pengamatan Shafie et al. (2011), komposisi batu bara, yang lebih polutif dalam konteks emisi $\mathrm{CO}_{2}$, terus bertambah sejak tahun 1995.

Variabel-variabel utama dalam penelitian ini adalah PDB per kapita (PDB), kuadrat dari PDB per kapita $\left(\mathrm{PDB}^{2}\right)$ dan emisi karbondioksida $\left(\mathrm{CO}_{2}\right)$, sedangkan variabel lainnya merupakan variabel kontrol. Adapun PDB dan $\mathrm{CO}_{2}$ diklasifikasikan sebagai variabel endogen karena adanya dugaan hubungan saling memengaruhi dalam studi-studi 
terdahulu, sedangkan variabel lainnya merupakan variabel eksogen. Variabel-variabel kontrol yang digunakan dipilih berdasarkan pada studi-studi terdahulu. Variabel EN merupakan variabel yang umum dikaitkan dengan emisi $\mathrm{CO}_{2}$ seperti dalam beberapa penelitian terdahulu (Azlina et al., 2014; Hwang \& Yoo, 2014; Kristiani \& Soetjipto, 2019; Lim et al., 2014; Uchiyama, 2016). Variabel TR sebagai regressor PDB digunakan dalam penelitian Halicioglu (2009), Shahbaz et al. (2013), dan Sbia et al. (2014), sedangkan variabel TCS sebagai regressor PDB digunakan dalam penelitian Radulescu et al. (2019).

Sebelum dilakukan interpretasi, hasil regresi simultan dalam penelitian telah melalui uji diagnostik terlebih dahulu yang meliputi uji autokorelasi, uji normalitas, dan uji heteroskedastisitas. Uji autokorelasi dilakukan dengan metode LM Test (Gujarati \& Porter, 2009), uji normalitas dilakukan dengan memanfaatkan uji dari Jarque-Bera dan uji heteroskedastisitas dilakukan dengan metode Breusch-Pagan-Godfrey.

\section{Hasil dan Pembahasan}

\section{Temuan Eksistensi Hipotesis EKC}

Validasi hipotesis EKC dapat dibuktikan dengan hasil regresi ketika PDB memiliki pengaruh positif signifikan dan $\mathrm{PDB}^{2}$ memiliki pengaruh negatif signifikan terhadap $\mathrm{CO}_{2}$, sehingga dapat membentuk hubungan kurva $U$ terbalik. Dalam studi ini, nilai kedua variabel tersebut tidak signifikan sehingga hipotesis EKC tidak dapat tervalidasi baik di negara Indonesia, Thailand, Filipina, maupun Malaysia. Ringkasan hasil regresi 2SLS untuk keempat negara disajikan dalam Tabel 1.

Tabel 1. Hasil Regresi 2SLS Indonesia, Malaysia, Filipina, dan Thailand

\begin{tabular}{|c|c|c|c|c|c|}
\hline \multicolumn{2}{|c|}{ Variabel } & \multicolumn{4}{|c|}{ Koefisien/Negara } \\
\hline Dependen & Independen & Indonesia & Thailand & Filipina & Malaysia \\
\hline \multirow{8}{*}{$\mathrm{CO}_{2}$} & $\mathrm{C}$ & $-19,67869$ & 69,64286 & $-2,184466$ & $-18,27198$ \\
\hline & PDB & 1,716781 & $-0,500076$ & 0,684215 & $-0,288371$ \\
\hline & $\mathrm{PDB}^{2}$ & $-0,000223$ & $6,37 \mathrm{E}-05$ & $-0,000114$ & $-4,05 \mathrm{E}-06$ \\
\hline & EN & 0,362562 & $1,171726^{* *}$ & $1,546930^{*}$ & $1,804175^{*}$ \\
\hline & DIDN11 & $681,8927^{*}$ & - & - & - \\
\hline & DIDN13 & $-624,3595^{*}$ & - & - & - \\
\hline & DTHA & - & $-377,5850^{*}$ & - & . \\
\hline & DMYSEN & - & - & - & $966,6694^{*}$ \\
\hline \multirow[t]{8}{*}{ PDB } & $\mathrm{C}$ & $796,6810^{*}$ & $-5,403703$ & $28,42339^{*}$ & $160,0561^{*}$ \\
\hline & $\mathrm{CO}_{2}$ & $1,010181^{*}$ & $1,055208^{*}$ & $0,862503^{*}$ & $0,303946^{*}$ \\
\hline & TR & $-2,212537^{*}$ & $3,330680^{* *}$ & $-2,235317^{* * *}$ & $-10,98466$ \\
\hline & TCS & $-8,930471^{* * *}$ & $-20,06119$ & $-3,771091$ & 2,891102 \\
\hline & DIDN11 & $-658,3876^{*}$ & - & - & - \\
\hline & DIDN13 & $669,1039^{*}$ & - & - & - \\
\hline & DPHL & - & - & $-100,1767^{* *}$ & - \\
\hline & DMYS98 & - & - & - & $-772,4372^{*}$ \\
\hline
\end{tabular}

Tidak terbuktinya hipotesis EKC dalam kasus penelitian negara berkembang secara individu dapat mengindikasikan kenaikan pendapatan per kapita tidak atau belum dapat diikuti oleh peningkatan kesadaran lingkungan masyarakat di negara tersebut. Dalam konteks emisi karbon, kebijakan sektor energi dan transportasi dapat mencerminkan kesadaran lingkungan. Hal ini dikarenakan emisi karbon hampir seluruhnya disumbang oleh penggunaan bahan bakar fosil (fossil fuel) untuk kedua sektor tersebut. Dalam konteks kebijakan energi, Indonesia dan Filipina cenderung terus menambah porsi batu bara dalam 


\section{Emisi Karbon dan Produk Domestik Bruto: Investigasi Hipotesis Environmental Kuznets Curve. . .}

bauran energi. Thailand cenderung menambah porsi gas dalam bauran energi, sedangkan Malaysia cenderung menambah porsi gas dan batu bara. Menurut Union of Concerned Scientists USA (2014), emisi karbon gas lebih kecil 50-60\% dibandingkan batu bara dan 15$20 \%$ lebih kecil dibandingkan minyak. Dengan kata lain, batu bara adalah bahan bakar fosil paling polutif sedangkan gas adalah bahan bakar fosil yang relatif paling tidak polutif. Dilihat dari porsi energi terbarukan, keempat negara tersebut terbilang lambat dalam memanfaatkan energi terbarukan yang ramah lingkungan baik dari sisi riset, pengembangan, maupun implementasi. Negara-negara maju, tempat hipotesis EKC dapat terbukti, merupakan negara-negara yang biasanya memiliki kebijakan untuk mendorong riset, pengembangan, dan implementasi energi terbarukan baik melalui subsidi, dana bantuan, atau regulasi. Sebagai contoh, per tahun 2015, energi terbarukan sudah menyumbang 53,9\% dari sumber energi Swedia (Climate Action, 2017). Sementara itu, menurut data World Bank (2020) per tahun 2014 porsi energi terbarukan dalam bauran energi keempat negara yang diteliti masih berkisar di antara 8-20\%.

Dalam konteks kebijakan transportasi, kebijakan yang tidak mendukung terjadinya EKC dapat dilihat dari adopsi mobil listrik, subsidi bahan bakar, dan transportasi publik yang efisien. Keempat negara yang diteliti memiliki kebijakan subsidi bahan bakar dan cenderung lambat dalam mengadopsi mobil listrik. Kebijakan subsidi bahan bakar memiliki risiko untuk meningkatkan inefisiensi penggunaan bahan bakar sehingga emisi $\mathrm{CO}_{2}$ meningkat. Negara-negara maju di Eropa menerapkan kebijakan yang berkebalikan, yaitu pajak bahan bakar untuk mengurangi emisi $\mathrm{CO}_{2}$. Per Januari 2019, pajak bahan bakar Eropa berkisar di antara $€$ 0,36- $€ ~ 0,79$ per liter (Tax Foundation, 2019). Hal serupa juga terjadi pada adopsi mobil listrik. Negara-negara maju di Eropa memberikan insentif yang signifikan untuk meningkatkan penggunaan mobil listrik. Sebagai contoh, menurut Asosiasi produsen otomotif Eropa/Association des Constructeurs Europeens d'Automobiles per tahun 2018 Perancis dan Italia memberikan subsidi hingga $€ 6.000$ untuk pembelian mobil dengan tingkat emisi di bawah $20 \mathrm{~g} \mathrm{CO} / \mathrm{km}$ (Association des Constructeurs Europeens d'Automobiles, 2019).

Berdasarkan penjelasan-penjelasan tersebut, dapat disimpulkan bahwa hipotesis EKC tidak tervalidasi pada seluruh negara yang diteliti dalam penelitian ini (Indonesia, Thailand, Filipina, dan Malaysia) karena kebijakan energi dan transportasi di keempat negara yang belum berhasil menurunkan emisi karbon. Tidak tervalidasinya hipotesis EKC untuk emisi $\mathrm{CO}_{2}$ di negara berkembang secara individu tersebut sejalan dengan temuan-temuan dalam penelitian terdahulu (Azlina et al., 2014; Iskandar, 2019; Saboori et al., 2012). Hal tersebut kembali menggarisbawahi keterbatasan dalam penelitian yang menginvestigasi eksistensi EKC, yaitu penelitian secara individu pada negara berkembang cenderung tidak dapat memvalidasi hipotesis EKC, karena perubahan struktural ke arah perekonomian yang lebih ramah lingkungan belum atau tidak terjadi untuk negara berkembang.

\section{Temuan Hubungan antara Emisi $\mathrm{CO}_{2}$ dan PDB}

Keterkaitan antara $\mathrm{CO}_{2}$ dan $\mathrm{PDB}$ secara umum dapat dijelaskan dengan struktur perekonomian saat ini. Menurut data British Petroleum (2019), per tahun 2018 konsumsi energi dunia berdasarkan sumbernya masih didominasi minyak, gas, dan batu bara yang secara berturut-turut berkontribusi 34\%, 24\%, dan 27\%. Dengan kata lain, 85\% konsumsi energi dunia yang menggerakkan perekonomian global masih bersumber dari bahan bakar fosil, sehingga kerap kondisi ini disebut juga sebagai kondisi dengan perekonomian berbasis karbon (carbon based economy). Fakta tersebut menjelaskan bahwa kegiatan perekonomian yang sebagian besar membutuhkan energi seperti listrik untuk produksi dan rumah tangga, serta transportasi logistik maupun individu akan berjalan beriringan dengan peningkatan emisi $\mathrm{CO}_{2}$. 
Hasil analisis model simultan untuk Indonesia, Thailand, Filipina, dan Malaysia memperlihatkan hasil yang serupa, yaitu $\mathrm{CO}_{2}$ berpengaruh positif signifikan terhadap PDB, namun PDB tidak berpengaruh signifikan terhadap $\mathrm{CO}_{2}$. Hal itu menunjukkan bahwa peningkatan penggunaan energi yang menghasilkan buangan emisi $\mathrm{CO}_{2}$ terbukti masih menjadi pendorong aktivitas perekonomian di negara-negara yang diteliti, sebaliknya penurunan emisi $\mathrm{CO}_{2}$ berisiko menurunkan aktivitas ekonomi. Temuan tersebut mengindikasikan adanya tantangan bagi keempat negara untuk menyeimbangkan antara target pembangunan ekonomi dengan target pengurangan emisi karbon.

\section{Implikasi Temuan EKC dan Hubungan antara Emisi $\mathrm{CO}_{2}$ dan PDB}

Tidak tervalidasinya EKC di keempat negara menunjukkan perlunya pemerintah di negara masing-masing untuk mewaspadai peningkatan ekonomi yang tidak disertai dengan meningkatnya kesadaran lingkungan. Untuk itu, pemerintah perlu lebih proaktif dalam membuat kebijakan-kebijakan ekonomi yang ramah lingkungan seperti peningkatan porsi energi terbarukan dalam bauran energi, konservasi energi, efisiensi transportasi publik, serta adopsi mobil listrik. Penelitian-penelitian terdahulu yang tidak dapat memvalidasi eksistensi EKC seperti Azlina et al. (2014) dan Iskandar (2019) juga memberikan rekomendasi yang serupa terkait kebijakan energi dan transportasi. Namun demikian, hasil temuan pengaruh positif dari $\mathrm{CO}_{2}$ terhadap PDB dalam penelitian ini mengimplikasikan perlunya kehati-hatian pemerintah dalam menerapkan kebijakan tersebut untuk menghindari perlambatan pertumbuhan ekonomi.

Pada dasarnya, kebijakan pemerintah untuk memanfaatkan lebih banyak bahan bakar fosil untuk listrik dan transportasi dibandingkan energi terbarukan memiliki alasan ekonomi. Selama periode data yang diteliti dalam tulisan ini, biaya ekonomi (tanpa memperhitungkan eksternalitas negatif) untuk menggunakan bahan bakar fosil lebih murah dibandingkan menggunakan energi terbarukan (Ciarreta et al., 2014). Hal ini berarti bahwa apabila pemerintah memaksakan untuk meningkatkan porsi energi terbarukan, biaya untuk menjalankan aktivitas ekonomi di negara tersebut akan meningkat, sehingga pembangunan ekonomi berisiko terhambat.

Tren perbedaan biaya antara bahan bakar fosil dan energi terbarukan tersebut saat ini mulai berubah. Di negara-negara maju, biaya energi terbarukan mulai menjadi lebih efisien dibandingkan bahan bakar fosil (Dudley, 2019). Hal itu tidak terlepas dari insiasi riset dan implementasi energi terbarukan di negara-negara maju yang telah berjalan puluhan tahun. Sebagai contoh, pada tahun 1960-an, Amerika Serikat telah memulai pengembangan panel surya (Fraas, 2014). Di sisi lain, Indonesia, Thailand, Filipina, dan Malaysia sebagai negara berkembang tampak relatif terlambat dalam melakukan inisiasi kebijakan yang sama. Kondisi serupa juga terjadi untuk sektor transportasi, saat di negaranegara berkembang saat ini, mobil listrik dengan kelas yang sama masih berharga lebih mahal dibandingkan dengan mobil berbahan bakar fosil. Peran serta pemerintah dalam memberikan subsidi untuk kendaraan bertenaga listrik sepertinya perlu lebih digalakkan, seperti yang telah dilakukan oleh beberapa pemerintah negara Eropa dan China (Bloomberg, 2019). Salah satu tantangan dari fakta tersebut adalah karena adanya perbedaan prioritas dalam proses pembangunan antara negara maju dan berkembang, yang disebabkan kapasitas fiskal yang masih terbatas, negara-negara berkembang seperti Indonesia, Thailand, Filipina, dan Malaysia cenderung akan lebih memprioritaskan alokasi anggarannya pada pengembangan sektor-sektor dasar, yaitu pendidikan dan kesehatan (Lubis \& Saputra, 2016). Untuk mengatasi permasalahan tersebut, Sbia et al. (2014) menyarankan agar negara-negara berkembang mampu berinovasi di dalam menciptakan kebijakan yang mendorong percepatan investasi dan kerja sama di bidang energi terbarukan dan kendaraan listrik dengan negara maju. Kebijakan tersebut diharapkan dapat mendorong adopsi teknologi secara cepat dan efisien. Terkait hal itu, Uchiyama (2016) 
menambahkan bahwa dalam konteks pembangunan berwawasan lingkungan, negara berkembang memiliki potensi untuk mendapatkan latecomer advantage apabila mampu memanfaatkan teknologi yang berasal dari negara maju secara optimal.

\section{Komparasi Hubungan antara Emisi $\mathrm{CO}_{2}$ dan PDB antar Negara}

Hasil regresi untuk keempat negara menunjukkan bahwa variabel emisi karbondioksida per kapita $\left(\mathrm{CO}_{2}\right)$ berpengaruh positif signifikan pada PDB per kapita, namun tidak sebaliknya. Di Indonesia, $\mathrm{CO}_{2}$ berpengaruh signifikan positif terhadap PDB dengan koefisien sebesar 1,010181. Di Thailand, $\mathrm{CO}_{2}$ berpengaruh signifikan positif terhadap PDB dengan koefisien sebesar 1,055208. Di Filipina, $\mathrm{CO}_{2}$ berpengaruh signifikan positif terhadap $\mathrm{PDB}$ dengan koefisien sebesar 0,862503. Di Malaysia, $\mathrm{CO}_{2}$ berpengaruh signifikan positif terhadap PDB dengan koefisien sebesar 0,303946. Berdasarkan perbandingan koefisien hasil regresi tersebut, Thailand relatif paling efisien dalam konteks polusi emisi $\mathrm{CO}_{2}$. Di Thailand, setiap penggunaan energi yang menghasilkan $1 \mathrm{~kg}$ emisi $\mathrm{CO}_{2}$ per kapita, secara rata-rata dapat menghasilkan 1,055208 PDB per kapita, ceteris paribus. Efisiensi tersebut diduga didukung oleh kebijakan bauran energi dan struktur ekonomi Thailand. Dari sisi kebijakan energi, Thailand memiliki komposisi gas tertinggi dalam bauran energinya dibandingkan tiga negara lain dalam penelitian ini (Gambar 3). Per 2014, kontribusi gas yang merupakan bahan bakar fosil paling rendah emisi, mencapai $68,71 \%$ bauran energi Thailand.

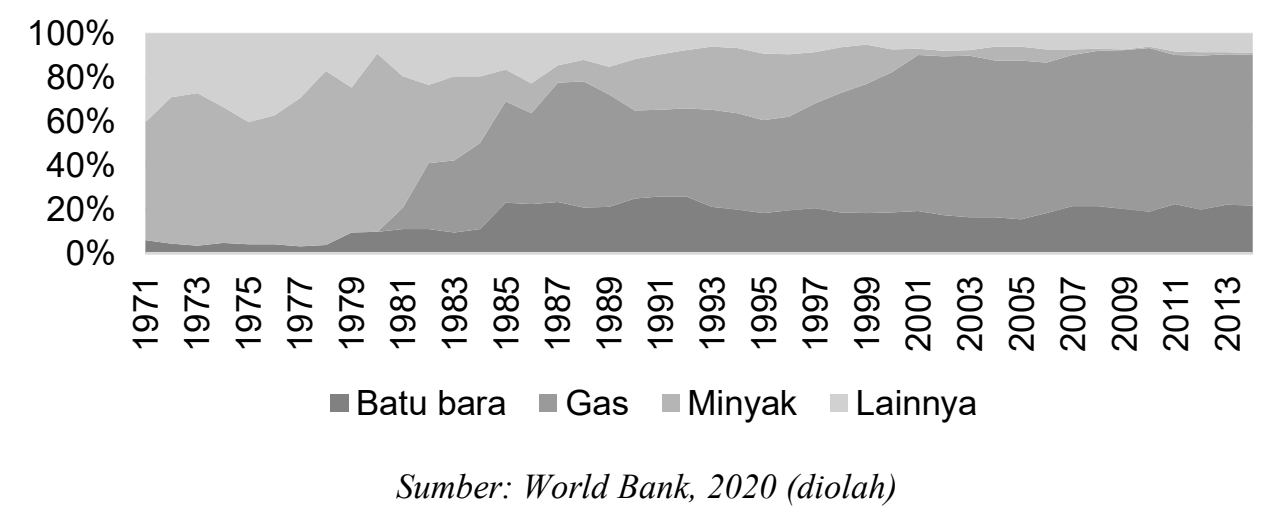

\section{Gambar 3. Perkembangan Kebijakan Energi Thailand 1980-2014}

Dilihat dari struktur ekonomi, efisiensi tersebut diduga didukung oleh struktur ekonomi Thailand yang sejak awal periode penelitian didominasi oleh sektor jasa. Per tahun 1971, sektor jasa sudah menyumbang 48,78\% terhadap PDB Thailand. Per tahun 2014, kontribusi sektor jasa tersebut sedikit meningkat menjadi 52,06\% (Gambar 4). Dalam hipotesis EKC, sektor jasa merupakan sektor yang akan mendominasi negara maju. Namun demikian, dalam konteks negara berkembang seperti Thailand, perlu analisis lebih lanjut mengenai detail data pembentuk sektor jasa tersebut yang saat ini belum (World Bank, 2020). Di luar hal tersebut, menurut Kementerian Energi Thailand (Thailand Ministry of Energy, 2018), terdapat indikasi pula bahwa masyarakat Thailand telah mulai mengalami peningkatan kesadaran akan lingkungan yang berkelanjutan. Hal ini terlihat dalam tantangan pembangunan energi di Thailand, yang salah satunya adalah penolakan masyarakat terhadap pembangkit listrik tenaga batu bara.

Indonesia menempati urutan kedua dari empat negara yang diteliti untuk efisiensi emisi $\mathrm{CO}_{2}$ dalam aktivitas ekonomi. Di Indonesia, setiap emisi $\mathrm{CO}_{2}$ per kapita $1 \mathrm{~kg}$, secara rata-rata dapat menghasilkan 1,010181 PDB per kapita, ceteris paribus. Kondisi tersebut 
terlepas dari kebijakan energi Indonesia yang cenderung menambah batu bara, bahan bakar fosil paling polutif, dalam komposisi bauran energi. Per akhir tahun 2014, batu bara menyumbang 52,45\% terhadap bauran energi Indonesia (Gambar 5). Dilihat dari struktur ekonomi, pertumbuhan kontribusi sektor jasa diduga menjadi salah satu penyebab efisiensi emisi $\mathrm{CO}_{2}$ di Indonesia. Kontribusi sektor jasa di Indonesia bertumbuh dari 29,33\% per tahun 1971 menjadi 43,66\% pada tahun 2014 (Gambar 6). Namun demikian, serupa dengan kasus Thailand yang merupakan negara berkembang, sektor jasa disini bisa jadi berbeda dengan konteks sektor jasa di negara maju. Hal yang perlu diperhatikan dari Indonesia adalah perkembangan kebijakan pasca periode penelitian. Proyek pembangkit listrik 35.000 MW yang diinisiasi setelah 2014 menggunakan batu bara sebagai komponen utama bauran energi. Kebijakan tersebut memang berkaitan dengan ketersediaan SDA (resource endowment) batu bara yang melimpah di Indonesia, sehingga diproyeksi dapat lebih efisien dari sudut pandang ekonomi. Namun demikian, hal tersebut berisiko meningkatkan intensitas polusi $\mathrm{CO}_{2}$ di Indonesia.

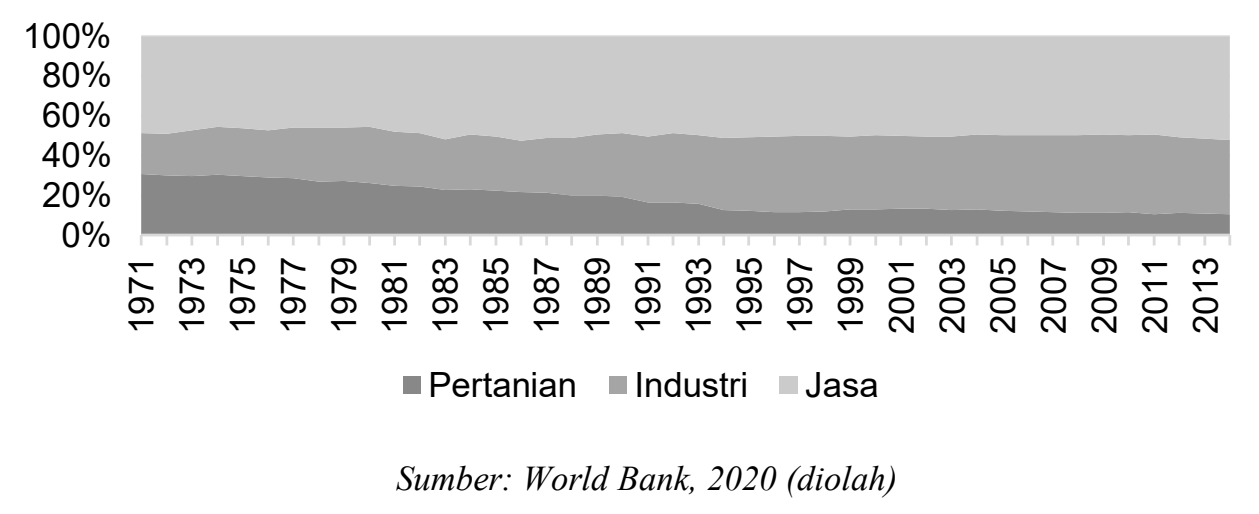

\section{Gambar 4. Perkembangan Struktur Ekonomi Thailand 1971-2014}

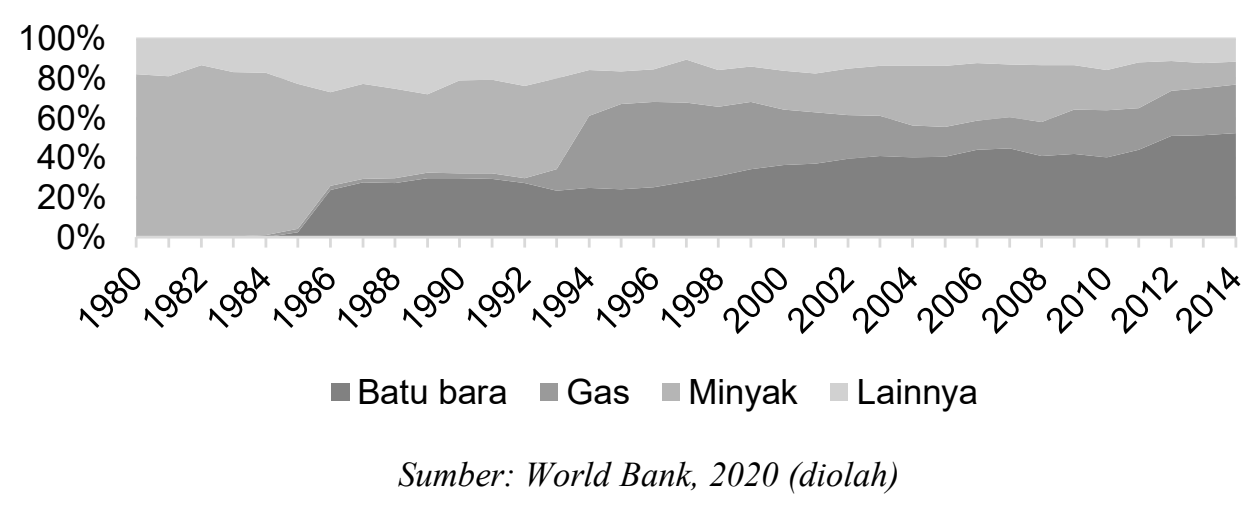

\section{Gambar 5. Perkembangan Kebijakan Energi Indonesia 1980-2014}

Di sisi lain, Indonesia juga sudah memiliki regulasi yang mendorong penggunaan energi terbarukan, seperti Peraturan Menteri Energi dan Sumber Daya Mineral (ESDM) Nomor 50 Tahun 2017 tentang Pemanfaatan Sumber Energi Terbarukan Untuk Penyediaan Tenaga Listrik. Regulasi tersebut memungkinkan rumah tangga yang memiliki panel surya untuk menjual kelebihan listriknya ke PLN. Permasalahan lain terkait emisi karbon di Indonesia adalah deforestasi dan kebakaran hutan. Model regresi dalam penelitian ini 
masih belum memperhitungkan dampak netto dari fenomena tersebut terhadap emisi $\mathrm{CO}_{2}$ di Indonesia.

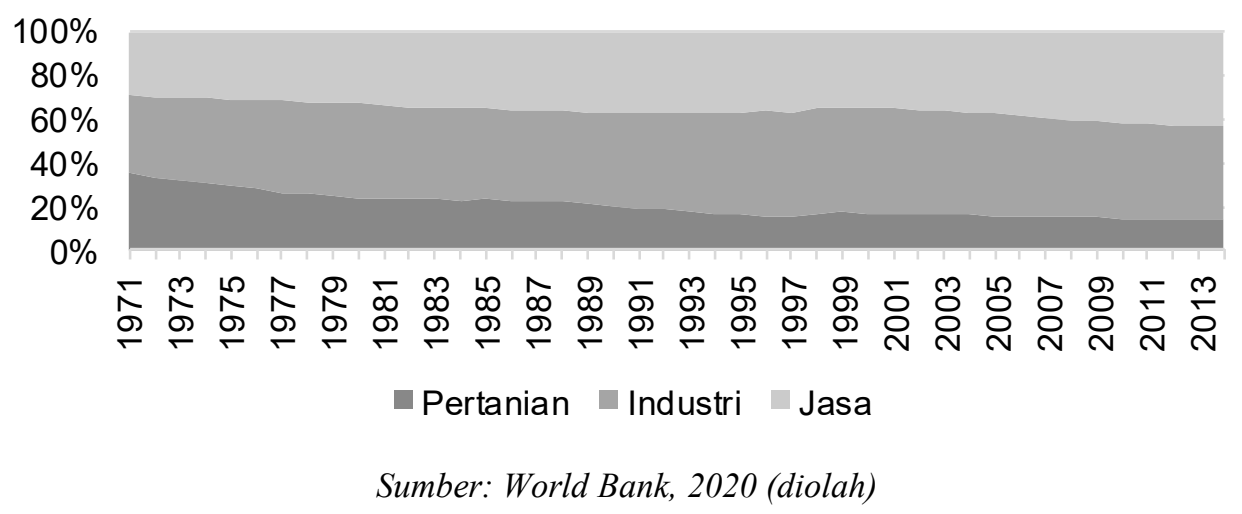

\section{Gambar 6. Perkembangan Struktur Ekonomi Indonesia 1971-2014}

Filipina menempati urutan ketiga berdasarkan koefisien pengaruh emisi $\mathrm{CO}_{2}$ per kapita terhadap PDB per kapita. Di Filipina, setiap penggunaan energi yang menghasilkan 1 $\mathrm{kg} \mathrm{CO}_{2}$ per kapita, secara rata-rata mampu meningkatkan PDB per kapita sebesar 0,862503 US\$ konstan 2010, ceteris paribus. Urutan ketiga Filipina diduga disebabkan oleh kebijakan energi di negara tersebut, yang mengandalkan batu bara menjadi sumber utama dalam bauran energi. Pada Gambar 7 terlihat bahwa hingga tahun 2014, batu bara menyumbang sekitar $42,78 \%$ dari bauran energi Filipina. Tinjauan terhadap struktur ekonomi Filipina belum mampu menjelaskan fenomena tersebut. Perekonomian Filipina memiliki kontribusi jasa yang tinggi, yang seharusnya tidak intensif energi atau emisi $\mathrm{CO}_{2}$ (Gambar 8). Pada akhir tahun 2014, sektor jasa di Filipina sudah menyumbang 56,04\% terhadap PDB, relatif seimbang dengan kontribusi sektor jasa di Thailand yang emisi $\mathrm{CO}_{2}$-nya lebih efisien.

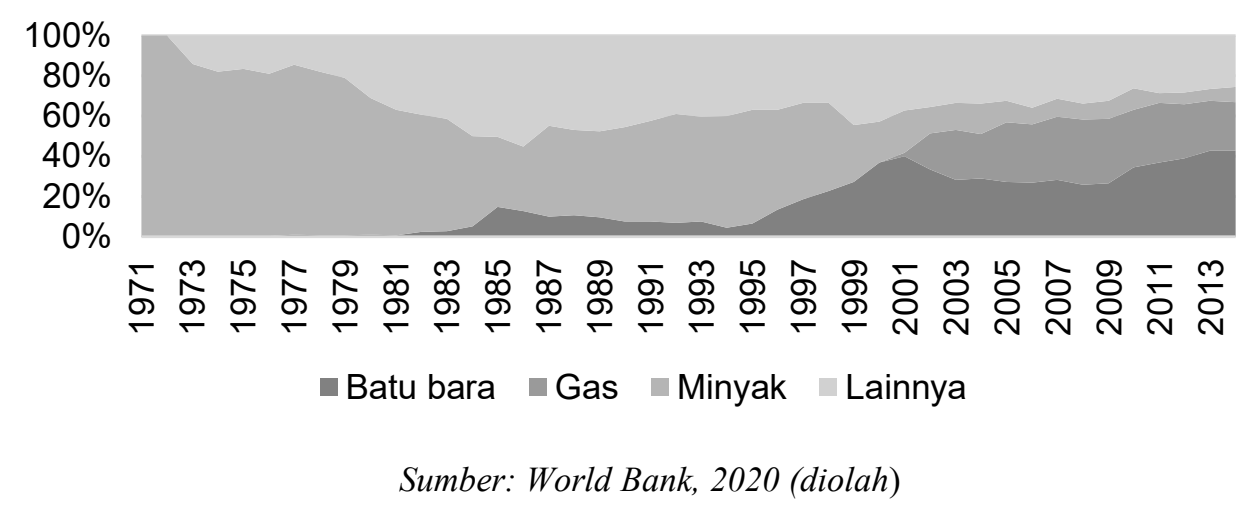

\section{Gambar 7. Perkembangan Kebijakan Energi Filipina 1971-2014}

Ulasan tentang sektor energi Filipina oleh Bunye (2019) menemukan bahwa 49\% dari bauran energi Filipina berasal dari impor. Kondisi tersebut berakibat pada harga energi yang harus dibayar oleh Filipina menjadi lebih mahal, sehingga efisiensi emisi $\mathrm{CO}_{2}$ tercatat lebih rendah. Permasalahan lainnya di Filipina adalah sektor transportasi yang menggunakan 34,9\% dari total konsumsi energi. Hal ini berimplikasi bahwa kebijakan untuk menciptakan efisiensi transportasi di Filipina dapat lebih efektif untuk meningkatkan efisiensi emisi $\mathrm{CO}_{2}$. Pasca periode penelitian, terdapat kebijakan pada tahun 2018 yang cukup berpotensi meningkatkan efisiensi emisi $\mathrm{CO}_{2}$. Departemen Energi Filipina 
menerapkan regulasi yang membolehkan konsumen untuk memilih sumber energi dari energi terbarukan (Green Energy Option Program). Namun demikian, efektivitas dari kebijakan ini juga sangat bergantung pada kesadaran lingkungan dari masyarakat Filipina.

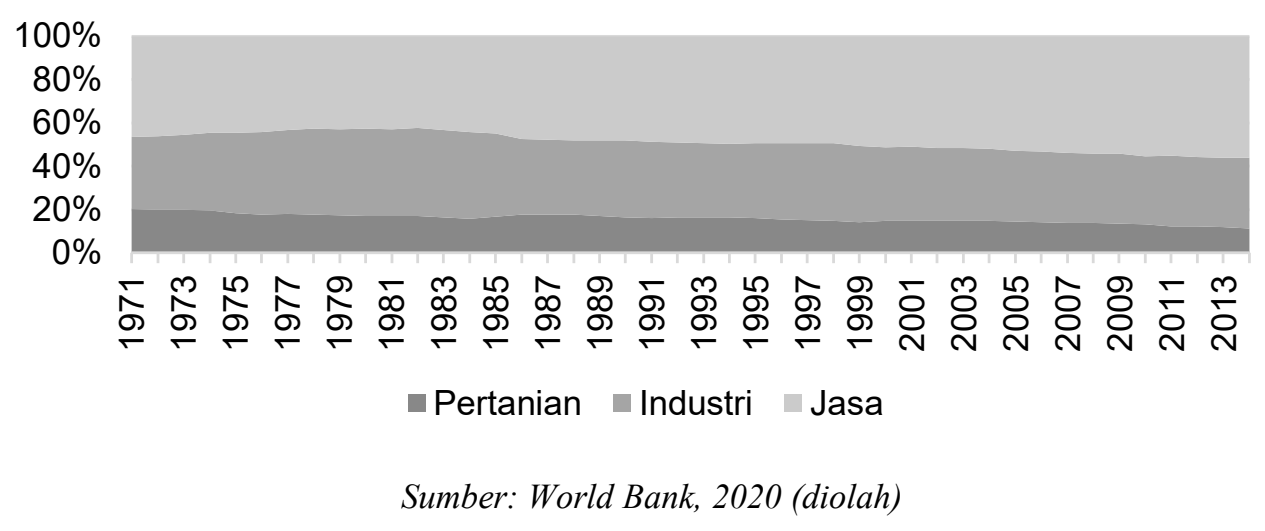

Gambar 8. Perkembangan Struktur Ekonomi Filipina 1971-2014

Malaysia menduduki urutan terakhir dari empat negara dalam besaran koefisien pengaruh emisi $\mathrm{CO}_{2}$ per kapita terhadap PDB per kapita. Di Malaysia, setiap penggunaan energi yang menghasilkan $1 \mathrm{~kg} \mathrm{CO}_{2}$ per kapita, secara rata-rata hanya mampu meningkatkan PDB per kapita sebesar 0,303946 US\$ konstan 2010, ceteris paribus. Kebijakan bauran energi di Malaysia mampu sedikit menjelaskan fenomena ini. Menurut Shafie et al. (2011), Malaysia memiliki kebijakan untuk meningkatkan porsi batu bara dalam bauran energinya selama periode pengamatan (1995-2009). Mengacu data World Bank (2020), per tahun 2014, batu bara menyumbang hingga 37,86\% terhadap komposisi bauran energi Malaysia (Gambar 9). Namun demikian, porsi tersebut masih lebih rendah dibandingkan porsi batu bara dalam bauran energi Indonesia dan Filipina yang menyumbang lebih dari 50\%.

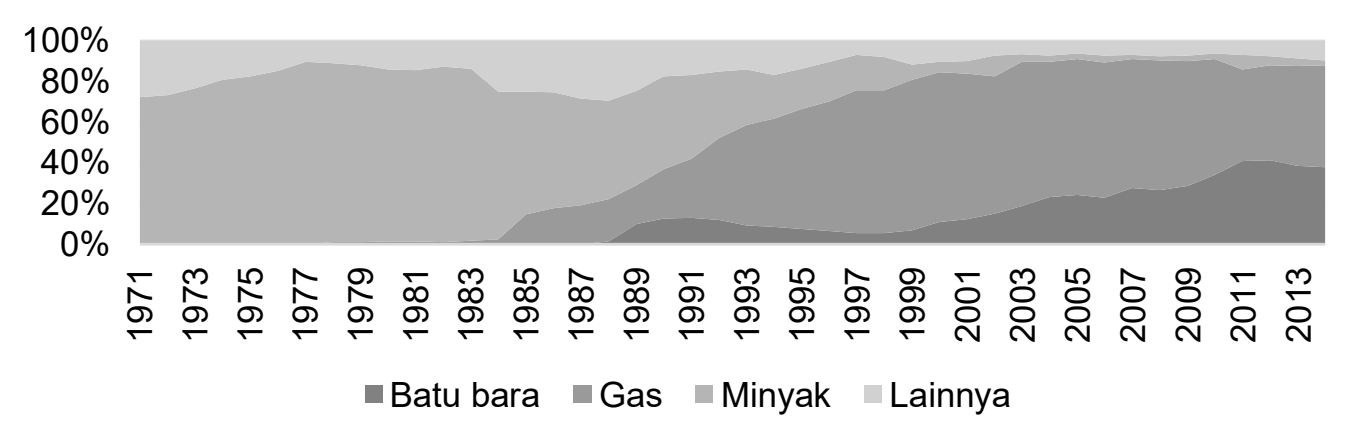

Sumber: World Bank, 2020 (diolah)

\section{Gambar 9. Perkembangan Kebijakan Energi Malaysia 1971-2014}

Faktor lain yang diduga menjadi penyebab rendahnya efisiensi emisi $\mathrm{CO}_{2}$ Malaysia adalah porsi sektor industri dalam struktur ekonominya. Seperti tampak pada Gambar 10, agak berbeda dengan tiga negara sebelumnya, porsi sektor industri dalam perekonomian Malaysia meskipun menurun, namun terlihat tinggi sejak awal hingga akhir periode penelitian (1971-2014). Pada tahun 1971, porsi sektor industri Malaysia sebesar 51,20\% dan di tahun 2014 tercatat sekitar 39,26\%. Penjelasan lain mengenai Malaysia dapat dilihat 


\section{Emisi Karbon dan Produk Domestik Bruto: Investigasi Hipotesis Environmental Kuznets Curve .. .}

dari konsumsi energi per kapita. Malaysia terindikasi kurang efisien dalam konsumsi energi, bahkan ketika dibandingkan dengan negara upper-middle income lainnya seperti China, Turki, dan Brazil. Menurut data World Bank (2020), per tahun 2014, konsumsi energi Malaysia, China, Turki, dan Brazil, dalam satuan kg setara minyak per kapita, secara berturut-turut adalah 3.003,45, 2.236,73, 1.651,361, 1.495,54. Menurut Economic Research Institute for ASEAN and East Asia (2017), per tahun 2015 45\% dari total konsumsi energi Malaysia digunakan untuk sektor transportasi, sehingga Malaysia serupa dengan Filipina dalam hal efisiensi transportasi. Menurut Oh et al. (2018), Pemerintah Malaysia selama bertahun-tahun membatasi harga gas domestik sebesar kurang dari setengah dibandingkan harga pasarnya. Kebijakan tersebut diduga memicu konsumsi energi yang tidak efisien.

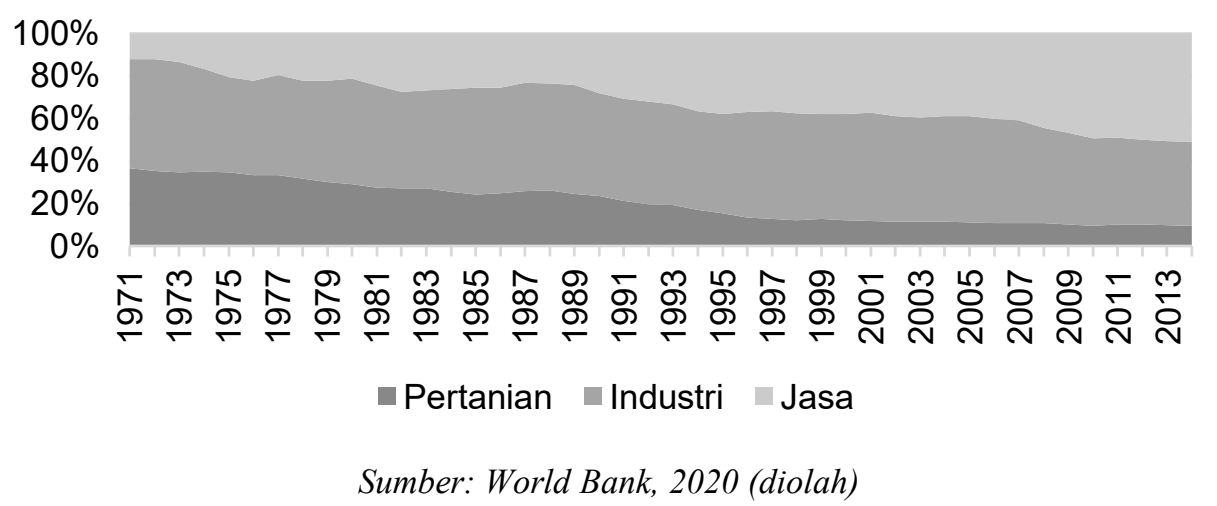

Gambar 10. Perkembangan Struktur Ekonomi Malaysia 1971-2014

\section{Hasil Regresi Variabel-Variabel Kontrol}

Dalam penelitian ini, variabel-variabel kontrol yang digunakan meliputi variabel nondummy (EN, Tr, dan TCS) dan variabel dummy. Variabel konsumsi energi (EN) berpengaruh positif terhadap $\mathrm{CO}_{2}$ pada keempat negara, sejalan dengan penelitianpenelitian terdahulu seperti Ang (2007) dan Azlina et al. (2014). Namun demikian, pengaruh ENhanya signifikan secara statistik di Filipina, Thailand $(\alpha=10 \%)$, dan Malaysia. Variabel rasio perdagangan pada PDB $(T r)$ berpengaruh negatif signifikan $(\alpha=10 \%)$ terhadap PDB pada Indonesia dan Filipina, sedangkan pada Thailand dan Malaysia, pengaruhnya positif signifikan $(\alpha=5 \%)$, serupa dengan temuan Halicioglu (2009). Variabel porsi konsumsi dalam PDB (TCS) terhadap PDB berpengaruh negatif, namun hanya signifikan pada Indonesia, Thailand $(\alpha=5 \%)$, dan Filipina $(\alpha=10 \%)$. Pengaruh variabel TCS tersebut sejalan dengan temuan dalam studi Radulescu et al. (2019). Untuk variabel-variabel kontrol dummy, variabel krisis ekonomi memiliki pengaruh negatif signifkan terhadap $\mathrm{CO}_{2}$ di Thailand $(D T H A)$ dan memiliki pengaruh negatif signifikan terhadap PDB di Filipina (DPHL) dan Malaysia (DMYS98). Di Indonesia, variabel awal dampak moratorium lahan (DIDN11) memiliki dampak positif signifikan terhadap $\mathrm{CO}_{2}$, sedangkan variabel akhir dampak moratorium lahan (DIDN13) memiliki dampak negatif signifikan terhadap $\mathrm{CO}_{2}$. Adapun variabel perubahan kebijakan energi di Malaysia (DMYSEN) berdampak positif signifikan terhadap $\mathrm{CO}_{2}$.

Uji diagnostik yang dilakukan atas seluruh persamaan regresi yang diteliti meliputi uji autokorelasi, normalitas, dan heteroskedastisitas. Hasil uji autokorelasi, normalitas, dan heteroskedastisitas menunjukkan tidak ditemukan adanya pelanggaran asumsi klasik dalam model yang digunakan. Hasil uji normalitas menunjukkan nilai prob. Jarque-Bera berkisar pada 0,620233-0,947108, berada di atas nilai $\alpha=5 \%$. Hasil uji heteroskedastisitas dengan metode Breusch-Pagan-Godfrey menunjukkan nilai prob. chi-square berkisar pada 0,05430,8181 , berada di atas $\alpha=5 \%$. 


\section{Kesimpulan}

Berdasarkan hasil regresi variabel emisi karbondioksida $\left(\mathrm{CO}_{2}\right)$, produk domestik bruto per kapita (PDB), dan variabel kuadrat dari $\mathrm{PDB}\left(\mathrm{PDB}^{2}\right)$, hipotesis EKC yang menjelaskan hubungan antara PDB per kapita dan emisi $\mathrm{CO}_{2}$ per kapita membentuk kurva $\mathrm{U}$ terbalik tidak terbukti di Indonesia, Thailand, Filipina, dan Malaysia. Hal tersebut mengindikasikan kenaikan taraf ekonomi yang terjadi selama periode 1971-2014 belum diiringi peningkatan kesadaran lingkungan publik di tiap-tiap negara. Oleh karena itu, pemerintah perlu lebih proaktif dalam membuat kebijakan-kebijakan ekonomi yang berwawasan lingkungan dan meningkatkan kesadaran masyarakat.

Hubungan antara PDB dan $\mathrm{CO}_{2}$ berjalan satu arah dari $\mathrm{CO}_{2}$ terhadap PDB dengan pengaruh positif baik di Indonesia, Thailand, Filipina, maupun Malaysia. Hal ini berimplikasi pada risiko melambatnya pertumbuhan ekonomi apabila kebijakan untuk menurunkan emisi $\mathrm{CO}_{2}$ diterapkan. Faktor perbedaan harga antara energi ramah lingkungan dan energi berbahan bakar fosil, serta biaya dan waktu riset untuk pengembangan energi ramah lingkungan diduga menjadi penyebab terjadinya kondisi tersebut. Oleh karena itu, untuk terjadinya trade-off pembangunan ekonomi dan konservasi lingkungan, kebijakan ekonomi untuk menurunkan emisi $\mathrm{CO}_{2}$ sebaiknya berupa insentif investasi dan kerja sama sektor energi terbarukan dan transportasi ramah lingkungan dengan negara maju. Selain itu, khusus untuk Malaysia dan Filipina, kebijakan efisiensi emisi $\mathrm{CO}_{2}$ dapat diarahkan pada efisiensi sektor transportasi mengingat konsumsi energi terbesar di dua negara tersebut berasal dari sektor transportasi.

Berdasarkan koefisien pengaruh $\mathrm{CO}_{2}$ terhadap $\mathrm{PDB}$, urutan efisiensi emisi $\mathrm{CO}_{2}$ dalam meningkatkan aktivitas ekonomi dari tertinggi ke terendah adalah Thailand, Indonesia, Filipina, dan Malaysia. Efisiensi emisi di Thailand didukung oleh tingginya porsi gas dalam bauran energi dan porsi sektor jasa dalam struktur ekonomi. Penerapan kebijakan bauran energi serupa berpotensi meningkatkan efisiensi emisi di negara lainnya. Namun demikian, aspek biaya dan ketersediaan sumber daya perlu diperhitungkan terlebih dahulu mengingat adanya kasus inefisiensi energi di Malaysia dan kasus dominasi impor dalam bauran energi Filipina. Peningkatan porsi sektor jasa dalam struktur ekonomi juga berpotensi meningkatkan efisiensi emisi untuk negara lainnya.

\section{Daftar Pustaka}

Anatasia, V. (2015). The causal relationship between GDP, exports, energy consumption, and $\mathrm{CO}_{2}$ in Thailand and Malaysia. International Journal of Economic Perspectives, 9(4), 37-48.

Ang, J. B. (2007). $\mathrm{CO}_{2}$ emissions, energy consumption, and output in France. Energy Policy, 35(10), 4772-4778. doi:10.1016/j.enpol.2007.03.032.

Association des Constructeurs Europeens d'Automobiles. (2019). Interactive map: Electric vehicle purchase incentives per country in Europe. Retrieved from https://www.acea.be/statistics/article/interactivemap-electric-vehicle-incentives-per-country-in-europe-2018.

Azlina, A. A., Law, S. H., \& Mustapha, N. H. N. (2014). Dynamic linkages among transport energy consumption, income and $\mathrm{CO}_{2}$ emission in Malaysia. Energy Policy, 73, 598-606. doi:10.1016/j.enpol.2014.05.046.

Bachelard, M. (2014). World's worst illegal logging in Indonesia. Retrieved from https://www.smh.com.au/national/victoria/worlds-worst-illegal-logging-in-indonesia-20140629zsq5j.html.

Bloomberg. (2019). China considers cutting electric-car subsidies again. Retrieved from https://www.bloomberg.com/news/articles/2019-11-08/china-is-considering-cutting-electric-carsubsidies-again.

British Petroleum. (2019). Statistical review of world energy 2019. London: British Petroleum.

Bunye, P. (2019). Philippines energy outlook 2020. Retrieved from https://www.globallegalinsights.com/practice-areas/energy-laws-and- 


\section{Emisi Karbon dan Produk Domestik Bruto: Investigasi Hipotesis Environmental Kuznets Curve .. .}

regulations/philippines\#chaptercontent3.

Caraka, R. E., Saputra, P. M. A., Wijaya, N., Ulkhaq, M. M., \& Subair, M. (2018). Postal and trade network data within ASEAN countries and beyond. In Journal of Physics: Conference Series (Vol. 1025). doi:10.1088/1742-6596/1025/1/012117.

Ciarreta, A., Espinosa, M. P., \& Pizarro-Irizar, C. (2014). Is green energy expensive? Empirical evidence from the Spanish electricity market. Energy Policy, 69, 205-215. doi:10.1016/j.enpol.2014.02.025.

Climate Action. (2017). Sweden and Norway to extend renewable power subsidy scheme. Retrieved from https://www.climateaction.org/news/sweden-and-norway-to-extend-renewable-power-subsidy-scheme.

Detragiache, E., \& Gupta, P. (2006). Foreign banks in emerging market crises: Evidence from Malaysia. Journal of Financial Stability, 2(3), 217-242. doi:10.1016/j.jfs.2006.06.001.

Dudley, D. (2019). Renewable energy costs take another tumble, making fossil fuels look more expensive than ever. Retrieved from https://www.forbes.com/sites/dominicdudley/2019/05/29/renewable-energycosts-tumble/?sh=57b22990e8ce.

Economic Research Institute for ASEAN and East Asia. (2017). Energy and transport policy in Malaysia. In H. Kondo \& I. Kutani (Eds.), Sustainable development of the transport sector: Malaysia (ERIA Research, pp. 3-19). Economic Research Institute for ASEAN and East Asia. Retrieved from https://www.eria.org/uploads/media/11.ERIA_RPR_2017_10_Chapter_2.pdf.

Fraas, L. M. (2014). History of solar cell development. In Low-cost solar electric power (pp. 1-12). Springer. doi:10.1007/978-3-319-07530-3.

Ghosh, A., \& Rajan, R. S. (2009). Exchange rate pass-through in Korea and Thailand: Trends and determinants. Japan and the World Economy, 21(1), 55-70. doi:10.1016/j.japwor.2008.01.002.

Ghosh, S. (2010). Examining carbon emissions economic growth nexus for India: A multivariate cointegration approach. Energy Policy, 38(6), 3008-3014. doi:10.1016/j.enpol.2010.01.040.

Grossman, G. M., \& Krueger, A. B. (1995). Economic growth and the environment. The Quarterly Journal of Economics, 110(2), 353-377. doi:10.2307/2118443.

Gujarati, D. N., \& Porter, D. C. (2009). Basic econometrics (5th ed.). New York: McGraw-Hill Education.

Gunawan, H., \& Budi, G. S. (2017). Kajian emisi kendaraan di persimpangan Surabaya Tengah dan Timur serta potensi pengaruh terhadap kesehatan lingkungan setempat. Jurnal Wilayah dan Lingkungan, 5(2), 113124. doi:10.14710/jwl.5.2.113-124.

Halicioglu, F. (2009). An econometric study of $\mathrm{CO}_{2}$ emissions, energy consumption, income and foreign trade in Turkey. Energy Policy, 373), 1156-1164. doi:10.1016/j.enpol.2008.11.012.

Hitz, S., \& Smith, J. (2004). Estimating global impacts from climate change. Global Environmental Change, 14(3), 201-218. doi:10.1016/j.gloenvcha.2004.04.010.

Holden, K., Thompson, J., \& Ruangrit, Y. (2005). The Asian crisis and calendar effects on stock returns in Thailand. European Journal of Operational Research, 163(1), 242-252. doi:10.1016/j.ejor.2004.01.015.

Hwang, J. H., \& Yoo, S. H. (2014). Energy consumption, $\mathrm{CO}_{2}$ emissions, and economic growth: Evidence from Indonesia. Quality \& Quantity, 48(1), 63-73. doi:10.1007/s11135-012-9749-5.

Index Mundi. (2020). Price trend of palm oil. Retrieved from https://www.indexmundi.com/commodities/?commodity=palm-oil\&months $=300$.

Intergovernmental Panel on Climate Change. (2018). Global warming of $1.5^{\circ} \mathrm{C}$. Retrieved from https://www.ipcc.ch/sr15/.

Iskandar, A. (2019). Economic growth and $\mathrm{CO}_{2}$ emissions in Indonesia: Investigating the environmental Kuznets Curve Hypothesis existence. Jurnal BPPK: Badan Pendidikan dan Pelatihan Keuangan, 12(1), 42-52. doi:10.48108/jurnalbppk.v12i1.369.

Kristiani, A. W., \& Soetjipto, W. (2019). Urbanisasi, konsumsi energi, dan emisi $\mathrm{CO}_{2}$ : Adakah perbedaan korelasinya di Kawasan Barat Indonesia (KBI) dan Kawasan Timur Indonesia (KTI)? Jurnal Wilayah dan Lingkungan, 73), 166-180. doi:10.14710/jwl.7.3.166-180.

Lim, K. M., Lim, S. Y., \& Yoo, S. H. (2014). Oil consumption, $\mathrm{CO}_{2}$ emission, and economic growth: Evidence from the Philippines. Sustainability, 6(2), 967-979. doi:10.3390/su6020967.

Lubis, R. F., \& Saputra, P. M. A. (2016). The Middle-Income Trap: Is there a way out for Asian Countries? Journal of Indonesian Economy and Business, 29(3), 273-287. doi:10.22146/jieb.10316.

Oh, T. H., Hasanuzzaman, M., Selvaraj, J., Teo, S. C., \& Chua, S. C. (2018). Energy policy and alternative energy 
in Malaysia: Issues and challenges for sustainable growth - An update. Renewable and Sustainable Energy Reviews, 81(2), 3021-3031. doi:10.1016/j.rser.2017.06.112.

Organisation for Economic Cooperation and Development. (2008). OECD key environmental indicators. Paris: OECD Environment Directorate.

Panayotou, T. (1993). Empirical tests and policy analysis of environmental degradation at different stages of economic development (ILO Working Papers). Geneva: International Labour Organization.

Partnership for Market Readiness. (2018). Pengantar pasar karbon untuk pengendalian perubahan iklim. Jakarta.

Radulescu, M., Serbanescu, L., \& Sinisi, C. I. (2019). Consumption vs investments for stimulating economic growth and employment in the CEE Countries - a panel analysis. Economic Research-Ekonomska Istraživanja, 32(1), 2329-2353. doi:10.1080/1331677X.2019.1642789.

Saboori, B., Sulaiman, J. Bin, \& Mohd, S. (2012). An empirical analysis of the environmental Kuznets curve for $\mathrm{CO}_{2}$ emissions in Indonesia: the role of energy consumption and foreign trade. International Journal of Economics and Finance, 4(2), 243-251. doi:10.5539/ijef.v4n2p243.

Sbia, R., Shahbaz, M., \& Hamdi, H. (2014). A contribution of foreign direct investment, clean energy, trade openness, carbon emissions and economic growth to energy demand in UAE. Economic Modelling, 36, 191-197. doi:10.1016/j.econmod.2013.09.047.

Shafie, S. M., Mahlia, T. M. I., Masjuki, H. H., \& Andriyana, A. (2011). Current energy usage and sustainable energy in Malaysia: A review. Renewable and Sustainable Energy Reviews, 15(9), 4370-4377. doi:10.1016/j.rser.2011.07.113.

Shahbaz, M., Hye, Q. M. A., Tiwari, A. K., \& Leitão, N. C. (2013). Economic growth, energy consumption, financial development, international trade and $\mathrm{CO}_{2}$ emissions in Indonesia. Renewable and Sustainable Energy Reviews, 25, 109-121. doi:10.1016/j.rser.2013.04.009.

Stern, D. (2014). The environmental Kuznets curve: A primer (Working Papers 249424).

Subramaniam, T., \& Baharumshah, A. Z. (2011). Determinants of unemployment in the Philippines. The Empirical Economics Letters, 10(2), 1248-1257.

Supriadi, D., \& Ismail, M. (2012). Kajian hubungan resiprokal antara penerimaan dan pengeluaran pemerintah (studi kasus di Indonesia periode 1969-2011). Jurnal Ilmiah Mahasiswa FEB, 1(2).

Tax Foundation. (2019). Gas taxes in Europe. Retrieved from https://taxfoundation.org/gas-taxes-europe2019/.

Thailand Ministry of Energy. (2018). Thailand's energy policy and implementation for SDG 7. Retrieved from https://www.unece.org/fileadmin/DAM/energy/se/pp/eneff/9th_Forum_Kiev_Nov.18/12_Novemb er_2018/3_Sinsukprasert_Thailand.pdf.

Tol, R. S. J. (2012). On the uncertainty about the total economic impact of climate change. Environmental and Resource Economics, 53, 97-116. doi:10.1007/s10640-012-9549-3.

Tsujino, R., Yumoto, T., Kitamura, S., Djamaluddin, I., \& Darnaedi, D. (2016). History of forest loss and degradation in Indonesia. Land Use Policy, 57, 335-347. doi:10.1016/j.landusepol.2016.05.034.

Uchiyama, K. (2016). Environmental Kuznets curve hypothesis. In Environmental Kuznets Curve hypothesis and carbon dioxide emissions (pp. 11-29). Tokyo, Japan: Springer. doi:10.1007/978-4-431-55921-4.

Union of Concerned Scientists USA. (2014). Environmental impacts of natural gas. Retrieved from https://www.ucsusa.org/resources/environmental-impacts-natural-gas.

United Nations Framework Convention on Climate Change. (2016). Intended nationally determined contribution Republic of Indonesia. Retrieved from https://www4.unfccc.int/sites/submissions/INDC/Published\%20Documents/Indonesia/1/INDC_REP UBLIC\%200F\%20INDONESIA.pdf.

World Bank. (2020). World development indicators. Retrieved from https://databank.worldbank.org/source/world-development-indicators/preview/on.

World Resources Institute. (2017). Evaluating Indonesia's progress on its climate commitments. Retrieved from https://www.wri.org/blog/2017/10/evaluating-indonesias-progress-its-climate-commitment.

Zhang, X. P., \& Cheng, X. M. (2009). Energy consumption, carbon emissions, and economic growth in China. Ecological Economics, 68(10), 2706-2712. doi:10.1016/j.ecolecon.2009.05.011. 